\title{
State Intervention at the Cabbage-Roots: A Case Study from Kenya
}

\author{
Thomas Wolf
}

Just what is the Cooperative Society? You can have one for coffee or for maize, or for wheat flour or whatever can sit until next week and then be sold, but not for cabbage or other vegetables that will spoil tomorrow. It just can't work, or it could only work if they had an airplane to send the produce to Europe or America where there is a very high price. But who will agree to allow the Society to control this trade when the market is right there at Mombasa?!

Look! ... (A certain private trader) can easily fill his lorry with just his own produce and that of few other people, while the Society, with all its members, can't even fill its.

Why do I sell to him? He offers me a much better price for my strawberries, for example, so who needs a society?! These larger private traders know I grow such 'special' vegetables, so they come to me and pay more to make sure I don't sell elsewhere. I agree to this, and this builds up that seller's 'clout' by enabling him to get and keep good marketing contracts. Is this not a war?!

Remember that when ... (a certain private trader) was discovered buying potatoes from a member with an outstanding debt to the Society he was arrested and kept in remand for three days, and if he hadn't been able to hire an advocate he would have lost the case and gone to prison. All the people here were ready to go and attack the cooperative manager's clan then! Is that not a war?!

When private traders learn that prices are up in Mombasa, they pay more for our produce at once, but in the case of the Society, a committee has to meet which takes too long. And then these present members are ignorant; when our group was in control, things were better. But the manager came back from overseas and we were all removed, even though the records showed that there had been a lot of corruption before. But he came with the District Cooperative Officer 'in his pocket' - with the support of the government, speaking in the name of the President ! - so we had no chance...

\section{Preface}

The centre of a political system or market rather than the periphery tends to command attention when issues related to state economic intervention are considered. In general, this makes sense, since it is at the centre where policies are formulated and state interests are most clearly visible: likewise, performance within an economy's key sectors feeds back into policy making and implementation, thereby setting the parameters of fut ure change. Yet such analyses, of ten relying heavily on official rhetoric and other formal manifestations of state intent, ignore the economic actors themselves, especially their perceptions of the opportunities and constraints engendered by the interplay of state and market forces.

It may be useful, therefore, to present an example from the political and economic periphery. An adequate analysis of public intervention into production or distribution markets must consider not just a policy's goals and content, but also its full range of manifest and latent consequences. These relate to the distribution of material and symbolic resources and hence to the creation, elimination, bolstering and undermining of interests and groups entailed in its implementation. This brief case study, taken from Kenya's horticultural sector, shows how the 'failure' of a state policy actually reflects a wider set of irreconcilable goals, themselves an expression of the inherent contradictions between the bureaucratic and class interests the state represents. We are left asking ourselves whether such a 'failure' might not more accurately be considered a 'success'.

\section{The Local Setting}

Taita District, situated in Kenya's southeastern Coast 
Province, is in eco-demographic terms very much a microcosm of the whole count ry. ${ }^{1}$ While comprising a vast $17,000 \mathrm{sq} \mathrm{kms}$, nearly two-thirds of this area is semi-arid, 60 per cent being National Park land. As a result most of the district's 150,000 inhabitants are confined to the middle and highland zones of the Voi and Wundanyi divisions and to the Kilimanjaro runoff region at Taveta near the Tanzanian border. Indeed, about half of Taita's population - increasing at an annual rate of over three per cent -is found within Wundanyi's heavily congested highland zone, and it is there that the bulk of horticultural production is carried out. In common with other similar areas of Kenya, these riding population densities have encouraged a return to subsistence farming to meet basic and immediate household needs.

In Taita, it has been within the relatively well-watered and fertile Werugha valley that market agriculture has persisted. It is from there that this case study is taken.

The Werugha valley comprises an area of about $30 \mathrm{sq} \mathrm{kms}$ supporting some 3,000 households. In common with most of Taita's zone, the government's programme of land adjudication, consolidation and registration has been completed, so that agricultural plots now contain individual dwelling units, in contrast to the village clusters of agnatic lineages of an earlier period. The distribution-range of land holdings is also typical of the zone as a whole, with under half an acre per head. A sample obtained by this researcher in 1979, for example, found 111 households in Werugh a possessing 121 land parcels. These ranged in size from 0.6 to 10 acres, with a mean of 2.5 acres. The two leading households, with totals of 10 and 12 acres respectively, are among the biggest landowners in the entire highland zone. Although these differences are highly significant for the domestic units concerned (even if many of them also hold land in the lessfavoured middle and lower zones) this constitutes a rather modest distribution-range in national terms.

\section{Cash-Cropping and Marketing}

While at any one time over a third of all household heads in the highland zone are engaged in off-farm wage labour (and nearly all have done so at some point in their lives), cas h agriculture has a long history there and continues to be important in maintaining the economic viability of family units. In gross terms, coffee has contributed by far the most revenue to agricultural income in the peasant sector ever since the prohibition against its cultivation by Africans was

\footnotetext{
The material used in this paper was obtained in the course of fieldwork conducted in Kenya during 1978-81. It forms part of a DPhil thesis submitted in the Graduate Division of Politics. University of Sussex, in 1985 entitled 'Leadership, Resources, and Locality-Center Relations in Taita. A Political Sub-System of Kenya's Coast Province: 1960-1975'.
}

lifted after World War II. For various reasons, the 1,500 coffee growing households constitute only about 15 per cent of the total number of households, even in the highland zone to which its production is restricted. Participation in cash horticultural production, on the other hand, while yielding only about 60 per cent of coffee's revenue within Wundanyi Division, is much more widespread; nearly half of all households are involved in it for at least some point in the year. Because of the previous restrictions on coffee, the colonial authorities gave relatively early backing to produce-agriculture; this made it possible for the first generation of returned labour migrants to continue to participate in the cash economy after about 1930. Initially, it was Asian traders based at Voi and other lowland trading centres who provided the main link to external markets, and encouraged the cultivation of such 'non-perishables' as chillies and castor seeds.

World War II witnessed a dramatic increase in official attention in Taita, as was the case elsewhere. Situated just 100 miles (or five hours by rail) from the port city of Mombasa, Wundanyi's highland zone was less than a third the distance of similar crop-growing areas upcountry. To encourage both overall production and marketing efficiency, the authorities improved feeder roads and increased the programme of technical assistance. Most significantly, government established the Taita Vegetable Growers' Cooperative Society, offering exemption from military service to those who joined, and provided both a lorry for transport and two marketing stalls at the main produce market at Mombasa.

With collection centres throughout the highland zone, the Society flourished. This situation continued throughout the 1950s as restrictions on Kikuyu economic activity outside their own Central Province north of Nairobi helped maintain a high demand for Taita produce at the Coast. After 1957 and the lifting of the Mau Mau Emergency, however, the Society's fortunes took a dramatic turn for the worse. With mounting up-country competition and deliveries hindered by the impassable condition of important feeder roads during rainy seasons, it lost many of its most lucrative supply contracts. Further, as prices were thus driven down - increasing the Society's overheads - a number of leading growers in Taita, most of whom had been able to develop their own social and economic 'connections' while serving the cooperative as stall clerks in Mombasa, left the cooperative and established themselves as private traders. The net effect of these factors was unresolvable indebtedness and its liquidation by the Department of Cooperatives in 1962. It was reconstituted into a more modest body, the Ngangao Farmers' Cooperative Society, limited in operation to the Werugha valley. 
Since independence in 1963 the Society's fortunes have varied. On the one hand, substantial government inputs have helped to underwrite its survival. Indeed, as measured by total turnover, membership and unit payments to growers, considerable success was achieved. By 1970, supported by the earnings from contracts with new schools, prisons and tourist lodges in the district, Ngangao's membership reached 400, but this state of affairs was short lived.

Taita's contribution to the total pool of fresh produce in Mombasa had by this time levelled off at about a quarter. The Society's problems were mainly local in origin. A major factor was the completion of an allweather $(30$ mile) road from Wundanyi to Voi, together with the improvement of feeder roads to Werugha itself. The private transport of both produce - via the dozen or so lorries acquired by local entrepreneurs (including several of the leading growers) - and people - by a plethora of mini-buses (mainly Asian and Arab-owned) from Mombasa, brought about a steady decline in the Society's volume. On the one hand, larger-scale growers/traders, unencumbered by high administrative costs (including corruption), ${ }^{2}$ were able to offer consistently higher prices for produce. On the other hand, smaller-scale traders (often from among the de facto landless and including self-supporting women) likewise took advantage of these new transport opportunities and moved in to the sector, nibbling away, through kinship and other social ties, at the cooperative's supply-pool. ${ }^{3}$ The efforts of both categories of traders were abetted by the increasing need for immediate cash among households, making their cash transactions considerably more attractive than the Society's end-ofmonth payments. By the late 1970 s, with up to 80 produce traders making the twice-weekly night journeys by mini-bus to Mombasa, Ngangao's active membership had slipped to just over 100; and most of them were disposing of at least part of their production through private sales. As a result, with the prospect of the Society's final demise increasingly the subject of discussion between its staff, members and Cooperative Department Officials, the government was directly confronted with the consequences of its two-faced policy towards the marketing of fresh produce from this locality. ${ }^{4}$

\footnotetext{
An independent auditor calculated that the Society's administrative costs amounted to 47 per cent of its 1978 budget, leaving only 53 per cent for payments to produce-supplying members. This meant, for example, that private buycrs were offering twice the Society's price for tomatoes during much of that year.

In regional terms. such performance was by no means unicue; by 1970. over half of all cooperatives which had been registered in East Africa were defunct.

4 Indeed, according to an expatriate adviser attached to the Society. only two to five per cent of its members were taking all their produce to its stores by the end of the 1970s: most took only some. while others took none at all.
}

\section{Policy Goals, Outcomes and the Role of the Sate in Taita's Horticulture}

While certain aspects of the state's role in this sector have already been suggested, it needs to be considered more explicitly here. On the one hand, the state has supported this vegetable marketing cooperative in a variety of ways: the allocation of financial subsidies for its management (including expatriate personnel and transport); the provision of loans for members in the form of output and productivity-raising inputs such as seeds, fertilisers and insecticides (and the promise of even greater benefits of this nature in the future); and the use of its administrative agents to enforce compliance with the Society's bye-laws by threatening members who sell elsewhere (especially those with outstanding debts). At the same time, however, at least part of the responsibility for the penetration and vitality of private enterprise within this market, and thus of the cooperative's weakness, rests with the state itself. Most important here are the following: the Minister of Cooperatives' refusal to grant a produce-purchasing monopoly even within Ngangao's main catchment area ${ }^{5}$ and conversely, the ease with which private trading licences are issued ${ }^{6}$ and the laxity with which regulation is enforced at Mombasa, the failure to intervene to give the Society any marketing advantages with either private or public agents, the minimal policing of the members' sales and a near-total refusal to prosecute even those members discovered making illegal sales or staff engaging in corrupt practices.

How then should state policy and behaviour with regard to the competing interests in this market be evaluated? At the outset, it is necessary to be clear about the goals of the several parties actually involved, which can all be seen as embodying certain contradictions. Society members, for instance, want to maintain their access to the credits and loans the cooperative offers and indeed, to prevent its total collapse which would greatly enhance the 'purchasing power' of a few large-scale buyers. It is, after all, this same concern about the concentration of economic 'clout' that accounts for much of their sales to petty traders at the bottom of the entrepreneurial scale. Yet these same members also seek to maximise their income by selling to those paying the highest prices. These several marketing alternatives - the Society, large and small-scale traders - are thus seen by growers as constituting a total system of countervailing options, each of which has its own short and longer term advantages - though it must be added that the great increase in the number of prospective private

\footnotetext{
5 The Kenyan Minister for Cooperative Development is authorised to issuc such an order when he estimates that at least 60 per cent of a given crop is handled by a society in a given area.

- In 1978, for instance, 79 such permits were issued by the local county council; these cost $40 /-$ each.
} 
buyers and the availability of agricultural inputs through a nearby Kenya Farmers' Association store has certainly made the society more expendable than it was previously. Viewed in these terms, even the Society's staff are subject to several contradictory impulses: wanting to build up its membership and volume, yet to extract maximum resources for personal gain without actually killing it, which would both end their access to such spoils and eliminate their visibility in the eyes of the state as well as of the community at large (in addition to exposing them to criminal prosecution).

What are the state's goals in this area? These can be summarised as follows: first, to foster the conditions for increased horticultural production and marketing so that the needs of rapidly growing rural and urban populations might be met; second, to justify its presence in the rural areas in general where its administrative purpose is often as much one of political control as of development; and third, to build and consolidate regime support among the most influential elements in rural society which - largely through the state's own actions - usually turn out to be the larger-scale growers and entrepreneurs.

\section{Conclusions}

The Society will soon die. Of course, the government is fire: if you step on it, you'll get burned. But there is no way to interfere with our vegetable selling. Threats against the members just drive them away. And does not the County Council get considerable revenue from the produce-selling licences it issues? And is not the County Council Clerk a kinsman of ... (one of the leading private traders)? And does not (the latter) have a greater volume of business than the whole Society? So for the government to interfere would start a real battle.

Many who have written about marketing cooperatives in Kenya have accepted the government's formal commitment to such forms of economic intervention at face value and sought to identify measures which would enhance their efficiency and growth. The case presented above from Taita, however, reveals how the state is itself largely responsible for the cooperative society's general failure by effectively putting 'interests' ahead of 'policy'.

Two basic factors determined this outcome. First, while it can be agreed that cooperatives can assist in institutionalising the power of the already economically privileged, the Taita Vegetable Society, built upon a relatively weak peasant sector base to begin with, has failed to attract and hold those few growers/traders who constitute that category. Second, and more fundamentally however, the horticultural sector as a whole within the agricultural economy and Taita's place within it - or indeed, within the political system itself - are largely peripheral. This has meant that the state has been unwilling to commit more than the minimum of its own resources in order to resolve 'conflict' within it. Thus, although the contradictions arising from this state of affairs are clearly visible, they threaten no-one and allow for three useful ends to be met: (i) the maintenance of an administrative presence by the state; (ii) the continued existence of the cooperative as an entrepreneurial training-ground for future entrants into the private sector; and (iii) the maximisation of horticultural output and delivery at the lowest possible prices for the more politically important, urban consumers.

Only by examining the actual consequences of a policy - including the perceptions of options and restrictions it engenders among the parties it affects - can questions relating to state intervention in markets, or other instances of public action or inaction, be answered. It may of course be the case that the longer-term effects of a given policy - perhaps, in this case, the ultimate destruction of the pettyproducing peasant class in Taita and the emergence of a small landed and agricultural-commercial elite may give rise to tensions which the state is incapable of resolving. Moreover, it is important to study the struggles being waged on the periphery by particular economic actors; these may reveal as much about how the state operates as those situated much closer to its economic and political centre.

\section{References}

Widstrand, C. G., ed., 1970, Co-operatives and Rural Development in East Africa, Scandinavian Institute of African Studies, Uppsala 